\title{
Function and Meaning of Kalosara Tradition on Tolaki Ethnic People (A Study of Cultural Socialin Konawe Regency, Southeast Province, Indonesia)
}

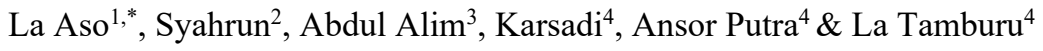 \\ ${ }^{1}$ Language and Literature Departemnt of Cultural Faculty, Halu Oleo University, Kendari, Indonesia \\ ${ }^{2}$ Archeology Departemnt of Cultural Faculty, Halu Oleo University, Kendari, Indonesia \\ ${ }^{3}$ Civic Education Department of Teacher Training and Educational Faculty, Halu Oleo University, Kendari, \\ Indonesia \\ ${ }^{4}$ SMAN 2 Sawerigading, of Muna Barat, Southeast Province, Indonesia \\ *Correspondence: Language and Literature Departemnt of Cultural Faculty, Halu Oleo University, Kendari, \\ Indonesia. E-mail: la_aso@yahoo.co.id
}

Received: November 30, 2019 Accepted: January 16, 2020 Online Published: January 20, 2020

doi:10.5430/sass.v7n1p1 URL: https://doi.org/10.5430/sass.v7n1p1

\begin{abstract}
This article discusses the function and meaning of kalosara tradition on Tolaki ethnic people in Konawe regency, Southeast Province based on the cultural social aspect. The objective of this research is to describe and to analyze the functions and menaings of kalosara tradition on Tolaki ethnic people in Konawe regency of Southeast province. The data of the research were collected through observation, interview, and documentation. The data then, were analyzed by descriptive qualitative method by using three steps of analyzing; they are reduction, presentation, and taking conclusion. The result of the research showed that Kalosara tradition has some functions and used in various rituals or ceremonies. The functions of kalosara tradition are: as a tool of peace to solve dispute, to keep solidarity, to keep consistency and polite attitudes, and to improve the social control on Tolaki ethnic people tradition. The equipment of Kalosara traditionis called kalo. Kalo has several kinds and each kind has certain meaning. Kalo is made from rattan in circle form to reflect and to give high respectful to the unity and solidarity on Tolaki ethnic group in Konawe regency. Kalo is put in a white cloth which is called siwole. The white cloth is interpreted as purity and sincerity. Purity and sincerity are two of main principles of Tolaki ethnic people.
\end{abstract}

Keywords: function, meaning, kalosara tradition, kalo, and Tolaki Ethnic people

\section{Introduction}

Social cultural aspects have important role in life management. Several companies use and apply social cultural system in human resources development. The social cultural values have positive effect for society life. If the values are integrated in each person, it can create harmony, peace, and poverty life.

Heritage or cultural treasure of the nation is the work of the creation, sense, and the initiation of the society in all regions in Indonesia which are produced individually or as a result of the interaction with other cultures throughout the history of its existence and continue to develop until now. The cultural heritage includes tangible things such as temple, palace, building, dance, music, language, manuscripts (ancient manuscripts), and intangibles such as philosophy, value, belief, habit, and convention.

Along with the times, cultural meaning and values begin to be forgotten. The rapid flow of globalization is feared by the national culture; especially the local culture will begin to erode. Foreign culture now becomes epidemic and begins to erode the local culture that is full of meaning. Therefore, the existence of local remains strong, it is necessary to maintain the local culture. The phenomenon of school-age children who are interested to the foreign culture make vigilance to raise and preserve local culture so it becomes an integrative part of learning local content at 
schools. Local culture is a culture that possessed by every region and reflecting the social conditions in its region. A number of things that included in local culture, such as folklore, folk songs, regional rituals, regional customs, and so forth. Therefore, it should be emphasized the importance of preserving local wealth that full of meanings in all life aspects and also can be used as a learning material for local content at schools. It is done in the effort to understand the values that contained in local culture, such as religious values, moral values, especially national values for students.

Tradition, as a descriptive category, is often used to signify a set of belief, customs, teachings, values, practices, or procedures (or any combinations of these) that are transmitted from generation to generation (Beckstein, 2017: 495). Adekola and Mwoye Charles Egbo (2016) state that many traditions have been invented on purpose, whether they are political or cultural, over short periods of time. One of the culture traditions in Southeast Province, especially in Konawe regency is kalosara. Kalosara is a tradition or custom which is very populer, especially in Southeast Provinve. It is one of traditions that owned by Tolaki ethnic people. It is most found in Konawe regency, Kolaka regency, and Kendari town of Southeast Province.This tradition has many functions and meanings. Several problems can be solved by using kalosara tradition. Kalosara tradition is used as a solution media and becomes the model for other people or ethnic group. It lines to Yadgar's View (2013: 456) who states that tradition is meaningless without its actual, contemporaneous interpretation-application by individuals and communities, thus highlighting the rather dynamic nature of tradition. The use of kalosara tradition just need low price. Therefore, kalosara tradition should be socialized to Tolaki ethnic people or to other ethnics in Southeast province.

Since last period, Tolaki ethnic people have used kalosara tradition as the life guide. By using kalosara tradition, Tolaki ethnic people get harmony, peace, and poverty life. It is used as the instrument in social life, like in handling lawsuit of land ownership, politic lawsuit, marriage problems, timing problem, and even to government issues or problems.

\section{Literature Review}

Basically, there are several previous studies which are relevant to this research. Tondrang (2000) discussed the Role of Kalosara Culture in Building Characters of Tolaki People. However, Tondrang did not explain the function and meaning of kalosara tradition on Tolaki ethnic. Tarimana (1993) investigated kalosara in his study about the Culture of Tolaki, but he did not explain deeply the meaning and function of kalosara. Tamburaka (2005) also studied about the role of kalo as symbol of symbolic communication media. In his study, Tamburaka also did not discuss the function and meaning of kalosara tradition on Tolaki ethnic.

Based on the explanation and previous studies above, it has not been found the study of the function and meaning of kalosara tradition on Tolaki ethnic people. This study, thus investigated the function and meaning of kalosara tradition on Tolaki ethnic people in Konawe regency, Southeast Province based on cultural social aspect.

This study is as the first action discusses the function and meaning of kalosara tradition on Tolaki ethnic people in Konawe Regency, Southeast province based on cultural social aspect. This research uses semiotic theory. In etymology, term of semiotic is derived from the Greek word "semeion" it means the sign or "seme". It means the interpreting of the sign. In terminology, semiotic can be defined as the science that the study about line of widely objects, events, all of the cultural as a sign. The signs is one of the stand in one the others or increasing of dimension that difference from the something, with using everything that use for translating one of the each other.

Barthes (1967) states that semiotic is a theory that can explain production and interpretation of meaning. The main principle is the meaning is created by action improvement and object that function as sign in its relations to other signs. Each sign can be interpreted in three steps, namely focusing to general symtomps, object/referent, and focuisng to interpretation.

In semiotic context, Geertz (1992, p. 76) says that a culture interpretation way/method, that is by describing configuration or meaning symbols deeply and comprehensively. Hoed (2008, p. 5 to 6$)$ states that the study of culture todays has become attention for semiotic theory development, either structuralist or pragmatics. Structural semiotic refers to sign theory of Saussure that present concept of signified and signifier, while pragmatic theory refers to theory of C.S. Pierce that present semiotic trichotomy. They are representament, object, and interpretant. Semiotic views culture as signs. Human as society members in their social cultural life give meanings to signs based on the legal convention. 


\section{Method}

This reseach uses qualitative descriptive method. Bogdan and Biklen (1992, p. 21 to 22) states that qualitative method is one of study procedures which create descriptive data.Wardiyanta (2006, p. 5)adds that descriptive study aims at decribing natural social phenomena systematically, factually, and acurately. It is as a field of research to collect qualitative data (Moleong, 2006 p.26).

The interpretation of data were done qualitatively, because of the relevant informationswere collected from informants that choosen purposively, such as the characters or custom figures in the society, government area that related in the regency, sub district, the village officials, and local society (Tolaki ethnic people) of Konawe regency.

In this research, the sources of the information can be classed in two categories, they are primary and secondary data. Primary data were obtained from the informants and the result of the observation. While the secondary data were used to fill the necessary of particular reconciled for something (documentation method). So, the data were collected through interview, observation, and documentation. The technique of data analysisin this studyrefers to Miles' and Huberman's (2009, p. 16 to 20) opinion that analyzing data in qualitative study consists of three lines activities that happen in coincide and simultaneous such as: data reduction, data display/presenting, and drawing a conclusion.

\section{Result and Discussion}

This part discusses the function and meaning of kalosara tradition on Tolaki ethnic people in Konawe regency, Southeast province based on cultural social aspect. Kalosara tradition has been used by Tolaki ethnic people as the life guide and reference. It has significant functions and meanings that have not been investigated clearly yet by the previous studies. Unfortunately, most Tolaki ethnicpe ople do not understand those functions and meanings. So, this researchis expected can give comprehensive description and understanding of kalosara tradition. The equipment of kalosara tradition is called kalo in which the first time was created by Lelesuwa which is made from three rattan windings. The rattan windings are used by Lalesuwa to divide Konawekingdom in four areas. Each area has one leader. Kalosara tradition is used by Tolaki ethnic people in many aspects and issues (Koodoh, et al., 2011, p.28). Kalo is made from uewai (rattan) in a circle form and the ends of the rattans are met in one knot, one is longer than one else. It is made in three windings. Besides, kalo is made from rattan that has not thorn and the tree is not high. In the era of Wakaila leadership, it was changed to uedatu(small rattan like grass), and it is then changed to uewatu (small rattan tree which is round and live without being planted) in the era of Lakidende leadership.

There are three kinds of kalo, namely: (1) kalo with the size of diameter in fourty five (45) centimeters. It is used for king or mokole and noble group/people/class or anakia. However, todays this kind is also for man of note like governor, regent, vice governor and vice regent, honorable guests, custom figures, in government problems, solving dispute, and enthronization of customs officials from pu'utobu to up. (2) kalo with the size of diameter in fourty (40) centimeters. It is used for susundonomo tuo group/class (middle group/class). However, todays this kind is also for head of district, custom figures, and information of death. (3) kalo with the size of diameter in twenty five (25) centimeters. It is used for the masses, casual peopleorservant group. Further, the form ofkalosara are varied, it can be colored (making shine) or without color as in the picture below. 


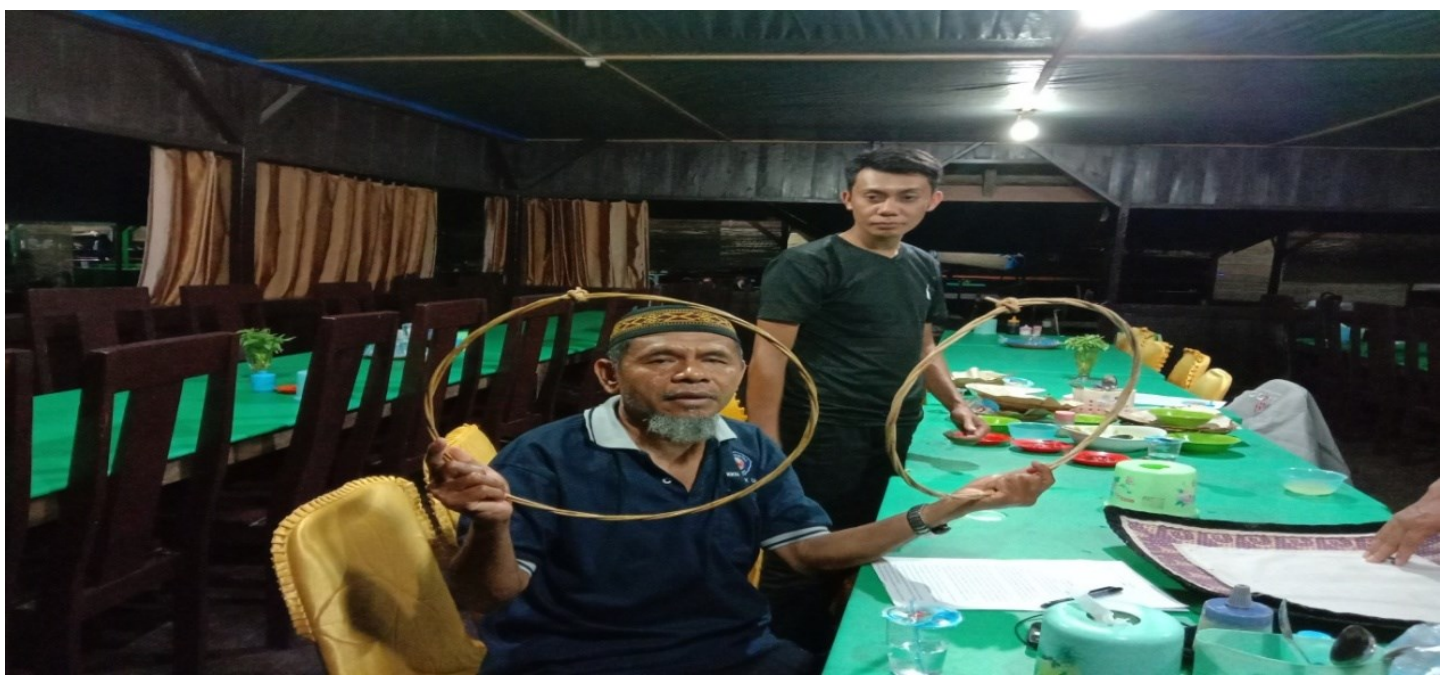

Picture 1. Model of Kalo

Picture 1 above shows the researcher was handling kalo. Kalo in the right hand of the researcher is colored and shine, and the kalo in the left hand of the researcher is plain or smooth without coloring. Besides,kalo is put in a place which is made from plaited mats of palm leaves and white cloth as its base, as presented in the pictures below.
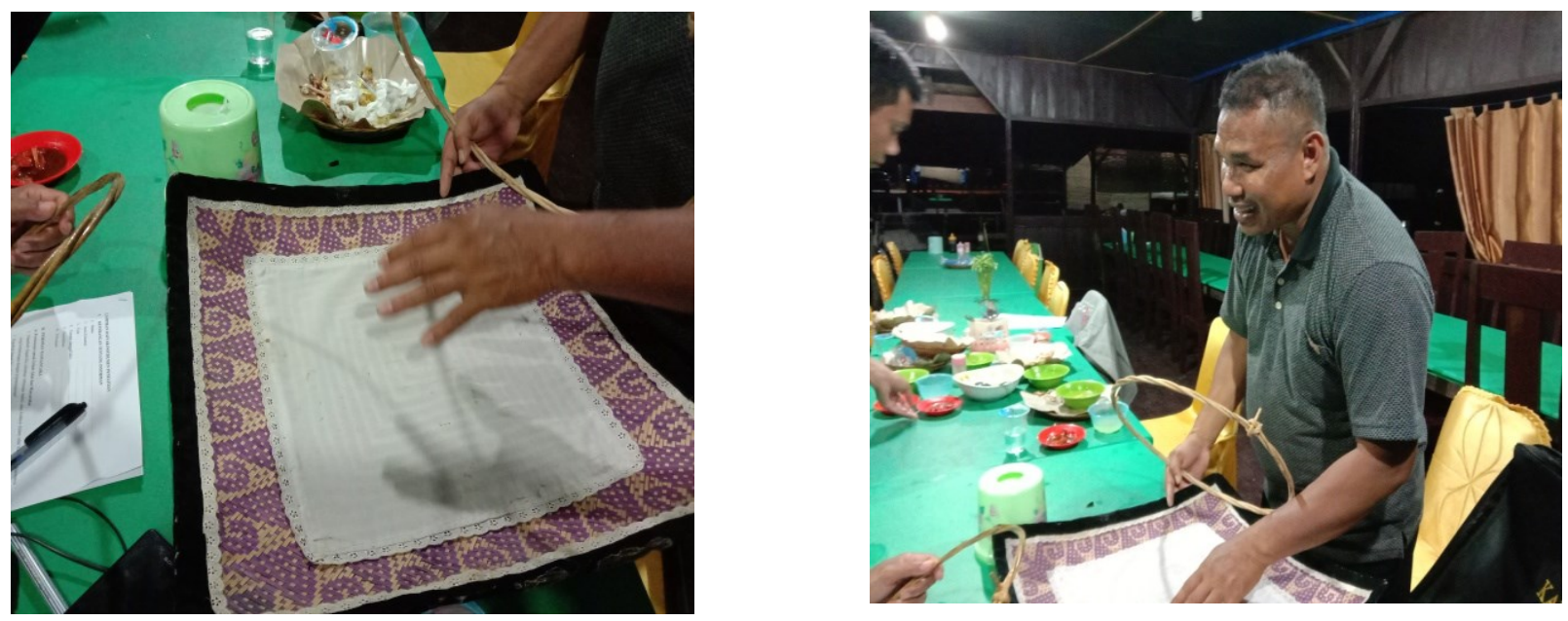

Picture 2. Scuttle to Put Kalo

Picture 2 above shows a custom figure as informant was explaining about the scuttle to put the kalo, in which the scuttle uses white cloth as its base. Further, kalo also can be divided in two forms. First, kalo which is put in neck and can not be gone down to shoulder; it is used to give decision of certain problems. Second, kalo which is put in the neck and can be gone down to shoulder; it is used to explain the concepts of leadership. This kalo is usually only owned by custom figure or custom spokesman, who is called as tolea. Besides, the head of village who is called as puutobu alsohas this kalo. However, puutobu just saves it and can not use this kalo because only custom figures who can use this kalo. For Tolakiness, the custom figures are like judge or custom judge who have right to give decision of problems that are faced by society.

Kalosara tradition only belongs to Tolakiethnic people. Tolaki ethnic people have the life phylosophy as mentioned in the terms:Inae merou, nggoiei toano dadio toono ihanuno 'Whoever is polite and respect the law/customs, people will be close to him/her"; Inae konasara iei inggoo pinesara, Inae liasara iei pinekasara 'Whoever respects the law/customs, he/she will be respected by the people, but whoever does not respect the law/customs, he/she will be given a sanction and he/she will not be respected by the people and will be given sanction'. The terms in thekalosara 
tradition have meanings that all people have to act politely based on the legal or custom law. Someone who has good attitude will be respected by other people. In vice versa, someone who has bad attitude will get social sanction in the society, such as if someone dies and he/she has not completed her/his custom doubt yet, most people will not bury $\mathrm{him} / \mathrm{her}$ untill his/her family complete or redeem the custom doubt. Likewise, if someone has bad attitude and not respect to custom law, people will not help him/her, and if he/she conducts a party, people will not present the party. It is a sanction that given to anyone who does not obey the custom law. Therefore, it something has been decided in meeting by using kalosara, all people have to obey it. It is the meaning of kalosara which has round, bound, and circle form; all people are bounded to kalosara.

Basically,kalois used in various rituals or parties with aims at respecting custom. For example, in the marriage ritual, both man and women family or relative are not allowed to speak by theirselves in the proposal step/ritual, except by custom sopkesman (tolea) who use kalo, mainly in giving decision. After giving decision by using kalosara, all people or those two families have to obey it. If they or one of them does not obey it, he/she will be given custom sanction. It means that one of the purposes of using kalosara is in order the society orp people are not allowed out from the custom law.

The form or kind of kalo has some meanings. The material of kalois from nature which is often used by Tolaki etnic people, namely rattan. Rattan has many advantages like as material to make basket, base of chair, mat, hat, something to put food and fruits. Besides, this rattan is very elastic and can be formed easily in various models because this material can not be broken easily. With the uniques of rattan, the use of it is as material of kalosurely has deep meaning. Besides, rattan which has many advatanges and often used in various rituals teach us indrectly that everyone has to be a good/polite person and needed by other people. Further, rattan which is tied strongly or has strong windings inkalo, it forces or urges the people to keep unity, peace, safety, and avoid any kinds of dispute.

Kalo which has three windings in circle form has certain meaning. Each of those three windings presents different object like in the family that consists of three elements, namely father, mother, and children. Those three elements are united in one bound as in the windings of kalo. Three windings also show that although there are several opinios or differences or choices, only one which is then believed or used altogether. There is not any one who can choose other opinios. Three windings also presents three elements in society, namely leader, custom figure, and casual people who live altogether, in peace and harmony, as in the idiom: we are one, one word and one soul".

Further, three windings inkalo also present three other elements, namely government, religion, and custom. Those elements are united in one winding as symbol of kalo.Besides, three elements of government, religion, and custom, it alsosupports each other to create the harmony, peace, and prosperity in the society life.

Besides the form of kalo, other interesting something in kalo are white cloth and scuttle to put the kalo. Kalo is put in a place which is made from plaited mats of palm leaves which is called as siwole andwhite cloth as its base. The scuttle and white cloth can be interpreted as custom for life guide and family community pattern. In which, the scuttle is like the place where the people live and white cloth as symbol of pure, peace, and symbol of custom. Kalosara tradition has been cultural base for each person in creating peace, together life, and save, mainly in keeping and using the law, eitehr custom law or state or forrmal law (Tawulo, et al., 1991; Tarimana, 1993; Tondrang, 2000).

Kalosara tradition on Tolaki ethnic people in Konawe regency which is used as a life guide has many functions. Based on the observation and analysis result of this research, the functions of kalosara tradition are keeping togetherness or unity spirit, social function, keeping consistency and polite attitude, and improving social control. Those functions are described below.

\subsection{Keeping Togethernessor Unity Spirit}

Tolaki ethnic people in Konawe regency always obey a law/custom that has been decided through kalosara tradition. They always participate in various rituals, and even before the ritual is carried out. They help each other from the preparation of the ritual until the ritual finished, including giving voluntary gift/present/money.

One of the signs that someone/family always participate in every party which is done by other people is there are many people who help him/her when celebrating party. In vice versa, when someone has a party and just a few people who come and help, it indicates that he/she also seldom participates in other people parties or he/she has low tolerance to other people.Togetherness unity is looked in each meeting to decide something or doing something by using kalosara. The function of kalosara indicates that all people have the same level, and unity and togetherness spirit are the main modal to reach purposes. Through kalosara, Tolaki ethnic people in Konawe regency can live in peace, safely, and without unsolved dispute.

The explanation above indicates that togetherness values has been implemented, mainly in traditional rituals. 
Togetherness values can be seen from various rituals of Tolaki ethnic people in Konawe regency. They give more respectful to collectivity, unity, and togetherness. High awareness and solidarity on Tolaki ethnic can solve any dispute and problem. Besides, they always work together and give respect to someone who helps them. It is the main principle for Tolaki people in Konawe Regency.

\subsection{Social Function}

Kalosara tradition has social function. Custom figures who want to use kalo should use custom clothes and it is still kept in Konawe regency. The presence of society, custom figures, head of village and district to give a speech in each ritual or party indicates that social communication has been created in the society life. Social communication occurs among the society, custom figures, head of village and district, and between someone/family who has party and visitors or guests.

Giving decision of certain problem by using kalo indicates that Tolaki ethnic people in Konawe regency are very careful in taking decision. Everything is decided together by using kalo media, and it has to be obeyed by all Tolaki ethnic people. It means that kalocan be used as a media to communicate well to other people.

\subsection{Keeping Consistency and Polite Attitude}

If a law/regulation has been decided through kalosara, all Tolaki ethnic people have to obey it. If someone does not obey it, he/she will get custom sanction. So, all Tolaki ethnic people have to be consistent to any decisions in kalosara tradition. The use of kalosara also has politeness meanings, in which it teaches us torespect to other people, mainly custom figures and government officials. Besides, the languages used in kalosara tradition must be polite.

\subsection{Improving Social Control}

The existence of kalosara tradition is able to support and urge people to control their attitude and behavior. All people have life guide and bounded to custom rules as controller of their life. The rules are used in many aspects like solving problem and dispute faced by people. The existence of kalosara can keep moral and ethics, mainly the consequences of globalization and modernization. In this case, kalosara tradition which is used as the life guide can be used as the control media and tool, so people will not be bad or deviated actions.

Kalosara tradition can be used as a control tool in the society life, social and group relation guide, evaluating standard of attitude, building communication, and as filter to select which one will be received or done and which one will be rejected. This tradition has moral value and norm, and can be used in planning and implementation of building project or program.

\section{Conclusion}

Based on the result and dicussion of this research, it can be concluded as follows.

By using kalosara tradition, Tolaki ethnic people get harmony, peace, and poverty life. Kalosara tradition is used as an instrument in social life, like in handling lawsuit of land ownership, political lawsuit, marriage problems, timing problem, and even to the government issues or problems. There are three kinds of kalo, namely: (1) kalo with the size of diameterin forty five (45) centimeters, it is used for the king ormokoleand the noble class or anakia. (2) kalowith the size of diameter in forty (40) centimeters, it is used fort h e the middle class or susundonomotuo, and (3) kalo with the size of diameter in twenty five (25) centimeters, it is used for the masses, casual classorservant class. The form or the kind of kalosara has some meanings.

Kalo is made from rattan. In Tolaki ethnic people, rattan has many advantages, for example it can be made for baskets, the base of chairs, mats, hats, etc. Further, rattan which is tied strongly or has strong windings in kalo, it forces or urges the people to keep unity, peace, safety, and avoid any kinds of dispute. Kalo which has three windings in circle form has certain meaning. Each of those three windings presents different object like in the family that consists of three elements, namely father, mother, and children. Those three elements are united in one bound as in the windings of kalo.Kalo is put in a place which is made from plaited mats of palm leaves which is called as siwole andwhite cloth as its base. The scuttle and white cloth can be interpreted as custom for life guide and family community pattern. In which, the scuttle is like the place where the people live and white cloth as symbol of pure, peace, and symbol of custom. The functions of kalosara tradition are to keep togetherness or unity spirit, social function, to keep consistency and polite attitude, and to improve social control. 


\section{References}

Adekola, G., \& Mwoye, C. E. (2016). Traditions and Customs in Community Development: The Case of Nkanu West and Nkanu East Local Government Areas of Enugu State, Nigeria. Journal of Education and Practice, $7(18)$.

Barthes, R. (1967). Elements of Semiology (trans. Annette Lavers \& Colin Smith). London: Jonathan Cape.

Beckstein, M. (2017). The Concept of a Living Tradition. European Journal of Social Theory, 20(4), $491-510$. https://doi.org/10.1177/1368431016668185

Bogdan, R., \& Biklen S. K.(1992). Qualitative Research for Education: an introduction to theory and methods / Robert C. Bogdan and Sari Knopp Biklen.Boston, MA: Allyn and Bacon.

Geertz, C. (1992). Tafsir Kebudayaan. Yogyakarta: Kanisius.

Hoed, B. H. (2008). Semiotik dan Dinamika Sosial Budaya. Depok Fakultas Ilmu. Pengetahuan Budaya (FIB) UI.

Koodoh, E., Alim, A., \& Bachruddin. (2011). Hukum Adat Orang Tolaki. Yogyakarta: Teras.

Miles, M. B., \& Huberman, A. M. (2009). Analisis Data Kualitatif. Jakarta: UI Press.

Moleong, L. J. (2000). Metode Penelitian Kualitatif. Bandung: Remaja Rosda Karya.

Tamburaka, B. (2012). Peran Kalo sebagai Media Komunikasi Simbolik. Kendari: Writing Collections.

Tarimana, A.(1993). Kebudayaan Tolaki. Jakarta: Balai Pustaka.

Tawulo, A. (1991). Mondau sebagai Sistem Perladangan Masyarakat Tolaki dan Pengaruhnya terhadap Kelesatarian Sumber Daya Hutan di Kabupaten Kendari. Kendari: Balai Penelitian Universitas Haluoleo.

Tondrang, A.(2000). Peranan Kalosara dalam Pembentukan Karakter Masyarakat Tolaki. Unaaha: Makalah dalam Rangka Musyawarah Adat I Suku Bangsa Tolaki.

Wardiyanti. (2006). Metode Penelitian Pariwisata. Yogyakarta: ANDI. 